\title{
Sindrom Sturge Weber
}

\author{
Putu Junara Putra, I Komang Kari
}

Sindrom Sturge Weber (SSW) atau disebut juga encephalofacialangiomatosis, merupakan kelainan neurokutaneus yang ditandai dengan angioma leptomeningeal dan angioma kutaneus pada kulit wajah (Port Wine stain), terutama khas pada daerah perjalanan nervus trigeminalis yaitu nervus oftalmikus (V1) dan nervus maksilaris (V2). Penyakit SSW disebabkan oleh anomali perkembangan bantalan vaskular pada stadium awal vaskularisasi otak yang mengakibatkan kelainan pada otak. Di Amerika, angka kejadian SSW diperkirakan sebesar 1 tiap 50.000. Kejadian SSW tidak dipengaruhi oleh ras dan jenis kelamin. Kelainan neurologis dan perkembangan meliputi kejang, kelemahan, stroke, sakit kepala, hemianopsi, retardasi mental, dan kelainan perkembangan. Diagnosis ditegakkan berdasarkan manifestasi klinis yang ditemukan pada tiga organ yaitu nervus, kulit dan mata, serta ditunjang oleh pemeriksaan pencitraan yaitu foto kepala, CT scan, MRI, single photon emission computed tomografi (SPECT), dan EEG.

\section{Kata kunci: Sindrom Sturge Weber}

S Sindrom Sturge Weber (SSW) atau disebut juga encephalofacialangiomatosis adalah suatu sindrom neurokutaneus yang ditandai dengan angioma pada muka yang secara tipikal terdapat pada muka bagian atas dan sebagian kulit kepala yang mengikuti perjalanan nervus trigeminus, kelainan vaskular dan kalsifikasi intrakranial ipsilateral, kejang, hemianopsia, dan glaukoma serta hemiparesis kontra lateral. ${ }^{1}$ SSW merupakan suatu kelainan kongenital yang jarang terjadi dan penyebab pastinya belum diketahui. ${ }^{1,2}$ Angka kejadian SSW di Amerika Serikat 1 : 50.000; ${ }^{1,3}$ dari 13 kasus SSW didapatkan 5 anak laki-laki dan 8 anak perempuan berumur antara 8-15

\footnotetext{
Alamat korespondensi:

PPDS IKA FK UNUD-RS Sanglah, Bagian Ilmu Kesehatan Anak, Denpasar; (Dr. Putu Junara Putra), Subbagian Neurologi IKA FK UNUD-RS Sanglah, Denpasar (Dr. I Komang Kari SpA)

Dr. Putu Junara Putra PPDS IKA FK. UNUD/ RS Sanglah, Bagian Ilmu Kesehatan Anak. Jl. Pulau Nias, Denpasar Telepon/Fax 0361244038 atau $0361-257387$
}

tahun. ${ }^{4,5}$ Riviello $\mathrm{JJ}^{2}$ melaporkan 2 dari 60 (3,3\%) pasien SSW meninggal, sedangkan Oakes $\mathrm{W}^{6}$ dikutip oleh Riviello JJ melaporkan 4 dari 30 (14\%) pasien SSW meninggal. Di Indonesia belum ada laporan data mengenai angka kejadian SSW.

\section{Etiologi}

Penyebab SSW belum diketahui secara pasti, namun demikian SSW dipastikan bukan karena suatu penyakit keturunan (walaupun pernah dilaporkan ditemukan pada keluarga SSW), ataupun bukan karena mengkonsumsi obat-obatan tertentu selama masa kehamilan. ${ }^{4,5}$ Keadaan ini diduga akibat anomali perkembangan bantalan kapiler vaskular pertama selama stadium awal vaskularisasi otak. Pada stadium ini, pasokan darah ke otak, meningen dan wajah mengalami reorganisasi, sedangkan lapisan ektoderm primitif berdiferensiasi menjadi kulit wajah bagian atas dan lobus oksipital otak. Leptomeningen yang 
menyelimuti otak, kaya akan jaringan vaskularisasi, sedangkan otak di bawahnya menjadi atropi dan mengalami kalsifikasi. Dalam keadaan normal, jaringan / pleksus vaskularisasi ini terbentuk pada minggu ke-enam usia kehamilan dan mengalami regresi pada usia kehamilan sembilan minggu. Kegagalan regresi ini menghasilkan jaringan residual vaskular yang akan menjadi bentukan angioma pada leptomeningen, muka, dan mata sisi ipsilateral. ${ }^{5}$ Terjadinya SSW diduga juga sebagai akibat mutasi spontan sel pada saat perkembangan janin. Sel yang mengalami mutasi ini akan membelah dan menghasilkan sel-sel yang bersifat sama dengan sel yang mengalami mutasi. Jika mutasi sel ini terjadi pada stadium awal perkembangan janin, maka akibat yang ditimbulkan akan menjadi lebih berat, karena semakin banyak sel yang membawa sifat sel yang bermutasi tersebut. ${ }^{1,5}$

\section{Patofisiologi}

Kelainan yang ditimbulkan pada SSW merupakan suatu bentuk gangguan perkembangan pembuluh darah, yang merupakan bagian dari pembuluh darah otak, yang terjadi selama kehamilan. Pembuluh darah yang abnormal ini biasanya ditemukan pada otak bagian oksipital atau parietal atau daerah lain dari otak, bahkan pada beberapa kasus tertentu ditemukan pada kedua belah sisi otak. Pembuluh darah otak yang abnormal berhubungan dengan fungsi otak yang abnormal. Dengan adanya pertumbuhan pada anak, sisi otak yang terkena akan menjadi atropi serta terjadi penumpukan kalsium pada pembuluh darah otak yang mengalami kelainan. Hal ini tampak pada pemeriksaan foto radiasi kepala dan CT scan.,

Mekanisme terjadinya penumpukan kalsium pada korteks belum diketahui secara pasti, namun fenomena ini diduga berhubungan dengan peningkatan permeabilitas kapiler akibat hipoksia jaringan korteks di bawah angiomatosis. ${ }^{7}$ Angimatosis pada wajah yang berupa bercak merah anggur yang dikenal dengan port wine stain (PWS) merupakan suatu pelebaran progresif sistem pembuluh darah kapilar yang abnormal. Kelainan ini terutama terdapat pada permukaan dermis dengan jarak $0,5 \mathrm{~mm}$ dari dermis, tetapi pada beberapa pasien dapat meluas ke seluruh dermis. Lesi ini terjadi karena hilangnya sel-sel nervus setempat, sehingga menyebabkan berkurangnya inervasi terhadap pembuluh darah. Inervasi pembuluh darah yang menurun mengakibatkan hilangnya regulasi aliran darah dermis dan terjadinya pelebaran pembuluh darah. ${ }^{4,5}$ Disfungsi neurologis disebabkan oleh karena efek sekunder kerusakan jaringan otak dan sekitarnya, manifestasinya berupa kejang, hemiparesis, atau defisit neurologis lain., ${ }^{5,8}$ Gambaran patologi kulit berupa dull red patches yang iregular yang terdistribusi pada satu atau lebih divisi nervus trigeminus, sedangkan di otak ditemukan kalsifikasi. ${ }^{8,9}$

\section{Manifestasi Klinik}

\section{Manifestasi pada kulit}

Nevus pada muka penderita SSW bersifat kongenital dan ada sejak lahir, biasanya unilateral dan melibatkan muka bagian atas, kelopak mata superior, atau daerah supra orbital. ${ }^{1,2,7}$ Nevus kongenital pada wajah terjadi akibat peningkatan jumlah kapilar di bawah permukaan kulit, permukaan rata, berwarna merah muda sampai ungu tua seperti warna anggur, dan tampak pucat pada penekanan. ${ }^{1,2}$ Tidak semua anak yang mempunyai PWS menderita SSW, hanya sekitar 10\% PWS yang merupakan gejala SSW. ${ }^{4,5}$ Luas PWS bervariasi, yang paling kecil biasanya hanya melibatkan kelopak mata bagian atas dan dahi, dapat meluas sampai pipi, hidung, bibir atas, mukosa nasofaring, dan membran koroid mata, sampai visera lainnya sesuai dengan perjalanan nervus trigeminus. Lesi pada kulit ini ditemukan 86\% bersifat unilateral dan $14 \%$ bersifat bilateral. ${ }^{4,5,10}$

Enjolras ${ }^{11}$ dikutip oleh Behrmen RE dkk. dalam penelitian retrospektif mendapatkan 12 orang SSW di antara 121 pasien dengan PWS. Dari penelitian tersebut diduga bahwa PWS dapat terdiri dari tipe V1 yaitu PWS yang mengenai nervus oftalmikus (kelopak mata atas dan dahi), type V2 yaitu PWS yang tidak mengenai nervus maksilaris (leher dan kelopak mata atas), dan tipe V3 yaitu PWS yang tidak mengenai nervus trigeminus. Peneliti menyimpulkan bahwa SSW hanya terjadi pada PWS tipe V1.

\section{Manifestasi pada sistem saraf}

- Kejang. Kejang pada awalnya bersifat lokal dan kontralateral, tetapi dapat pula berkembang menjadi kejang umum yang biasanya terjadi pada umur 3 
hari - 4 tahun. Kejang dapat bertambah berat dan semakin sering sesuai dengan bertambahnya umur. ${ }^{1,2}$ Tipe, frekuensi, dan derajat berat kejang tidak berhubungan dengan luas angioma pada kulit. Kejang terjadi oleh karena hasil iritasi kortikal oleh serebral angioma, yang diikuti dengan proses hipoksia, iskemia, dan gliosis. ${ }^{2,3,7}$

- Epilepsi. Epilepsi ditemukan pada 75-90\% SSW. ${ }^{2,3,7}$

- Hemiparesis. Hemiparesis bersifat kontralateral terhadap letak nevus pada wajah dengan insidens $25-56 \%$, terjadi akibat efek sekunder dari iskemia dengan oklusi pembuluh darah dan trombosis. Hemiparesis biasanya terjadi secara perlahan-lahan, dapat menetap dan menghilang dalam beberapa jam setelah kejang. Hemiparesis sering diikuti dengan hemiatropi anggota gerak, berkuranganya sensibilitas dan adanya hemianopsia homonim. Tonus otot bersifat spastik disertai gejala piramidal. 6,12,13

- Strokelike episode. Episode transient akan diikuti oleh episode yang menyerupai stroke. Keadaan ini ditemukan pada 14 dari 20 pasien SSW. ${ }^{14}$

- Retardasi mental. Retardasi mental terjadi pada 50\%-60\% pasien dan lebih banyak pada pasien dengan gangguan bilateral. Retardasi mental disebabkan karena kejang umum yang lama sehingga meningkatkan atropi otak akibat hipoksia yang luas. ${ }^{7,14}$

\section{Manifestasi pada mata}

- Glaukoma. Glaukoma terjadi bila PWS mengenai nervus oftalmikus, dengan insidens berkisar 30\%$71 \%$, dapat terjadi sejak lahir, sering ditemukan pada bagian unilateral dan ipsilateral dari PWS. ${ }_{2,7,15}$ Glaukoma pada SSW terjadi karena obstruksi mekanik pada sudut mata dan menyebabkan peningkatan tekanan vena episklera atau karena meningkatnya produksi air mata oleh angioma koroidal atau badan silier. ${ }^{2,7,16}$ Glaukoma yang tak tertangani dengan baik akan mengakibatkan kerusakan nervus mata, penurunan daya refraksi dan kebutaan. $2,5,7$

- Buftalmos. Buftalmos adalah pembesaran bola mata karena melonggarnya selaput pembungkus bola mata yang terjadi bersamaan dengan glaukoma.

\section{Pemeriksaan Penunjang}

\section{Gambaran radiologi}

Di samping pemeriksaan klinis, pencitraan neurologis (neuroimaging) merupakan pilihan metode dalam menegakkan diagnosis SSW. ${ }^{1,8,9}$

\section{Foto Rontgen kepala}

Pada foto Rontgen kepala akan tampak suatu gambaran klasik menyerupai "jalur kereta api” yang disebut tram line atau trolley track, yang merupakan gambaran proses kalsifikasi. ${ }^{1,2,7}$

\section{CT scan kepala}

Dapat menunjukkan kalsifikasi intrakranial. Kalsifikasi sering ditemukan pada daerah oksipital, parietooksipital atau pada daerah temporal, dan sangat jarang terjadi pada daerah frontal, selain itu sering ditemukan dengan atropi otak. ${ }^{1,7}$

\section{MRI}

MRI dapat menunjukkan pembuluh darah yang abnormal dan kalsifikasi intracranial. Kalsifikasi berbentuk garis lurus atau berkelok-kelok di daerah oksipital atau parieto-oksipital. 1,2,7,17

\section{Single photon emission computed tomografi (SPECT)}

Pinton $\mathrm{F} \mathrm{dkk.}{ }^{18}$ mengemukakan tentang keuntungan pemeriksaan SPECT dini pada pasien SSW untuk mendeteksi aliran darah serebral yang asimetris yang memperlihatkan hipometabolisme dan hipoperfusion pada otak yang mengalami malformasi. Dalam perkembangan teknologi selanjutnya Lee JS dkk. ${ }^{19}$ pada tahun 2001 melaporkan tentang penggunaan fluoro D-glucosa photon emission tomography (FDG PET) dalam mendeteksi beratnya kerusakan metabolisme korteks yang asimetri dan dapat memberikan informasi tentang prognosis pasien dengan SSW tersebut. 


\section{EEG}

EEG dilakukan bila ditemukan kejang, pada pemeriksaan ini akan tampak penurunan amplitudo dan frekuensi aktivitas elektrografi pada hemisfer yang terkena. Pemeriksaan ini juga dapat mendeteksi lokasi aktivitas kejang, yang merupakan gambaran kerusakan otak. ${ }^{7}$ Dilaporkan adanya reduksi unilateral melatarbelakangi gambaran amplitudo yang ditemukan pada saat tidur dan terjaga dengan prosedur aktivasi (hyperventilation and photic driving) menurun di bagian gambaran otak yang mengalami lesi. ${ }^{2}$

\section{Laboratorium}

Pemeriksaan laboratorium pada SSW tidak ada yang spesifik, hanya kadang ditemukan peningkatan protein pada cairan serebrospinalis yang menggambarkan adanya microhemorrhage.?

Pemeriksaan laboratorium lain yang diperlukan antara lain fungsi hati unutk melihat efek samping antikonvulsan yang diberikan pada pasien SSW yang bersifat hepatotoksik. ${ }^{5,7}$

\section{Diagnosis}

Diagnosis SSW ditegakkan berdasarkan manifestasi klinis yang ditemukan pada organ nervus, kulit dan mata, serta ditunjang oleh pemeriksaan radiologi, EEG dan laboratorium. Del Monte $\mathrm{MA}^{7}$ membagi SSW menjadi klasifikasi sebagai berikut:

- Complete trisymptomatic SSW : jika bermanifestasi lengkap pada tiga organ saraf, mata, dan kulit.

- Incomplete bisymptomatic SSW : terdiri dari Okulokutaneus yang meliputi mata dan kulit dan Neurokutaneus yang meliputi nervus dan kulit

- Incomplete monosimptomatic SSW: apabila mengenai neural atau kutaneus (PWS)

\section{Diagnosis Banding}

Beberapa kelainan neurukutaneus yang mempunyai manifestasi klinis menyerupai SSW di antaranya,

1. Klipel Trenaunay Weber Syndrome

Kelainan ini ditandai dengan ditemukannya PWS disertai hipertropi ekstremitas unilateral sejak lahir, dengan lokasi pada wajah, kulit kepala, dada, perut bahkan sampai ekstremitas, selain itu juga sering diikuti dengan kelainan pada mata, tulang, ginjal, kelenjar adrenal, dan hepar. Gambaran PWS dapat ditemukan pada lebih dari 1 lokasi. ${ }^{3,7,20}$

2. Neurofibromatosis

Neurofibromatosis merupakan kelainan pada kulit, susunan saraf pusat dan susunan saraf perifer, tulang, endokrin, gastrointestinal, serta pembuluh darah. Manifestasi klinis pada kulit berupa bercak kopi susu yang berwarna coklat terang (café au lait) yang disertai tumor kutan multipel yang bertangkai. Bercak muncul pada anak usia muda dan bertambah banyak sesuai dengan bertambahnya usia, dengan lokasi pada wajah, leher, badan dan ekstremitas. ${ }^{20,21}$ Manifestasi lain yang menyertainya adalah axillary freckling, lisch nodul, glioma pada optik, retardasi mental, perawakan pendek dan sering disertai dengan pubertas prekok, serta hipertensi. ${ }^{3,21}$

\section{Tuberous sclerosis}

Tuberos sclerosis merupakan kelainan degeneratif neuroektodermal yang ditandai oleh trias epilepsi, retardasi mental, dan adenoma sebaseum. Kejang merupakan gejala awal yang dapat muncul setiap saat setelah lahir. Kelainan ini merupakan salah satu penyebab utama retardasi mental dan epilepsi berat yang resisten terhadap obat. Adenoma sebaseum merupakan lesi angiofibroma dengan bentuk seperti kupu-kupu berwarna merah muda. Lesi ini jarang muncul saat lahir, biasanya berkembang antara umur 1-4 tahun dengan lokasi di hidung, pipi, dan dagu. ${ }^{3,8,20-22}$

\section{Tata laksana}

Pasien SSW tidak dapat disembuhkan, dengan pengobatan simptomatis. Kejang dan epilepsi diatasi dengan pemberian obat anti kejang seperti fenobarbital, dilantin, atau karbamazepin, atau anti epilepsi lain sesuai dengan kondisi pasien. Bila dengan pemberian obat ini kejang tidak berhenti, maka dapat dilakukan tindakan pembedahan berupa reseksi lobus otak yang terkena, reseksi korpus kalosum, atau bila diperlukan dilakukan hemisferektomi total. Hemis- 
ferektomi total hanya dilakukan pada bayi di bawah 1 tahun dengan kejang yang tidak dapat diatasi dengan pemberian obat anti kejang. ${ }^{8,23}$ Glaukoma harus dideteksi dan diobati secara dini dengan melakukan operasi atau pemberian tetes mata untuk mencegah kebutaan. Tindakan operasi trabekulektomi atau goniotomi dapat menjadi pilihan lain. ${ }^{15,16,24,25}$ Nevus pada wajah dapat dihilangkan dengan terapi laser, yang terbukti efektif menghancurkan lesi vaskular tanpa merusak kulit yang normal. ${ }^{7}$ Paresis atau paralisis yang biasanya hemi dan kontralateral terhadap letak lesi dapat ditangani dengan fisioterapi, berupa stimulasi, hidroterapi dan terapi wicara, sesuai dengan defisit neurologis atau keterlambatan yang terjadi pada pasien tersebut. ${ }^{7}$

\section{Prognosis}

Prognosis SSW tergantung luas bagian otak yang terkena, berhubungan dengan derajat keparahan serangan kejang dan cenderung menjadi progresif walaupun telah mendapatkan perawatan yang optimal. Dilaporkan banyak pasien menjadi lebih berat penyakitnya, epilepsi sulit dikendalikan, penglihatan terganggu bahkan dapat terjadi kebutaan, kelumpuhan fokal memburuk, dimensia dan meninggal. ${ }^{3}$

\section{Kesimpulan}

Sindrom Sturge Weber atau disebut juga encephalofacialangiomatosis adalah suatu sindrom neurokutaneus yang ditandai dengan angioma pada muka yang secara tipikal terdapat pada muka bagian atas dan sebagian kulit kepala yang mengikuti perjalanan nervus Trigeminus, kelainan vaskular dan kalsifikasi intrakranial ipsilateral, serta kejang, hemianopia dan glaukoma serta hemiparesis kontra lateral. Diagnosis SSW ditegakkan berdasarkan manifestasi klinis yang ditemukan antara lain pada sistem saraf, kulit, dan mata, serta ditunjang oleh pemeriksaan radiologi, EEG, dan laboratorium. Pengobatan SSW bersifat simptomatis dan prognosisnya tergantung pada luasnya bagian otak yang terkena yang berhubungan dengan beratnya serangan kejang dan cenderung menjadi progresif walaupun telah mendapatkan perawatan yang optimal.

\section{Daftar Pustaka}

1. Menkes JH. Dalam: Menkes JH, penyunting. Textbook of Child Neurology. Edisi ke-empat. Philadelphia: Lea and Febiger, 1990. h. 570-3.

2. Riviello JJ. Sturge Weber syndrome. eMed J 2001; 10:123-9. Sahala ML. Sindrom neurokutan. Dalam: Soetomenggolo T, Ismael S, penyunting. Buku Ajar Neurologi anak. Jakarta: BP IDAI, 1999. h. 299305.

3. Pediatric Database (PEDBASE). Sturge Weber Syndrome. Diperoleh dari; http://www.icondata.com/health/ pedbasel files/STURGE-W.HTM.

4. Behrman RE, Klliegman RM, Jenson HB. Neurocutaneous syndromes. Dalam: Behrman RE, Kliegman RM, Jenson HB, penyunting. Nelson textbook of pediatrics. Edisi ke-16. Philadelphia: WB Saunders, 2000. h.1838. Oakes W. Sturge Weber syndrome. eMed J 2001; 10:123-9.

5. Del Monte MA. Sturge Weber syndrome.eMed J 2001; 7. Sturge Weber Disease. Pediatric Encyclopedia. Health Central. Diperoleh dari; http://www. healthcentral. com/ peds/top/001426.cfm.

6. Berg BO. Neurocutaneous syndromes: Phamakotoses and allied condition. Dalam: Swaiman KF, penyunting. Pediatric Neurologic. Principles and Practice. St Louis: CV Mosby Co, 1989. h. 804-5

7. Portiilla P, Husson B, Lasjaunias P, Landrieu P. Sturge Weber disease with repercussion on the prenatal development of the serebral hemisphere. Am J Neuroradiol 2002; 23:490-2.

8. Enjolras. Sturge Weber syndrome Dalam: Behrman RE, Kliegman RM, Jenson HB, penyunting. Nelson Textbook of Pediatrics. Edisi ke-16. Philadelphia: WB Saunders, 2000. h. 1838.

9. Chapieski L. Psychology functioning in children and adolescent with Sturge Weber syndrome. J Child Neurol 2000; 15:660-5.

10. Kramer U, Kahana E, Horer Z, Zeez BB. Outcome of infant with unilateral Sturge Weber syndrome and early onset seizurs. Dev Med Child Neurol 2000; 42:756-9.

11. Sturge Weber syndrome. British Epilepsi Association. Information. Diperoleh dari; http://www.epilepsi.org.uk/ info/sturgfrm. html.

12. Witschel H, Fon RL. Hemangioma of the chorouid. A Clinicopathologic study of 71 cases and a review of the literature. Surv ophthalmology 1976; 20:415-31.

13. Iwach AG, Haskins HD, Hetheriston. Analysis of surgical and medical management of glaucoma in sturge 
weber syndrome. Ophtalmology 1990; 97:904-9.

14. Grifiths PD, Boodram MB, Susan Blaser, dkk. Abnormal ocular enhancement in Sturge-Weber Syndrome: Corelation of Ocular MR and CT Finding with clinical and intracranial imaging findings. Am J Neuroradiol 1996; 17:749-54.

15. Pinton F, Chiron C, Enjoiras O, Motte J, Syrota A, Dulac O. Early single photon emission computed tomography in Sturge Weber syndrome. J Neurol Neurosurg Psy 1997; 63:616-21.

16. Lee JS, Asano E, Muzik O. Correlation between clinical course and FDG PET finding. Neurology 2001;57:85-90.

17. Berg BO. Developmental disorders of the nervous system. Dalam :Berg BO Principles of child Neurology.New York: Mc Graw-Hill,1996. h. 924-5.
18. DeBella K, Szudek J, Friedman JM. Use of the National Institute of health criteria for diagnosis of neurofibromatosis 1 in children. Pediatrics 2000; 105:608-14.

19. Mac Collin, Mia A, Kwiatkowski, David B. Molecular genetic aspects of the phacomatoses: tuberous sclerosis complex and neurofibromatosis 1. Curr Opin Neurol 2001; 14:163-9.

20. Arzimanogiou AA, Andermann F, Aicardi J. Sturge Weber Syndrome. Indication and result of surgery in 20 patients. Neurology 2000;55-8

21. Kerrison JB. Neuro-opthalmology of the phacomatoses. Curr Opin Ophthalmol 2000; 11:413-20.

22. Bebin EM, Gomez MR. Prognosis in Sturge-Weber disease: comparison of unihemispheric and Bihemispheric involvement. J Child Neurol 1988 ; 3:181-4. 